\title{
Mechanisms of intracellular isosmotic regulation: Extracellular space of the shore crab Carcinus maenas in relation to environmental salinity
}

\author{
D. Siebers \& C. Lucu \\ Biologische Anstalt Helgoland (Zentrale); \\ Hamburg 50, Federal Republic of Germany
}

KURZFASSUNG: Mechanismen der intrazellulären isosmotischen Regulation: Der extrazelluläre Raum der Strandkrabbe Carcinus maenas in Abhängigkeit vom Salzgehalt. Durch Verdünnungsanalyse des markierten Polysaccharids ${ }^{14} \mathrm{C}$-Inulin und des Nahrungsmittelfarbstoffes Amaranth nach Injektion ins Hämocoel wurde der extrazelluläre Raum von Carcinus maenas bestimmt. Die Strandkrabben waren einen Monat lang in Salinitäten von 10-15\% gehalten worden. Die Größe des extrazellulären Raumes, die sich als weitgehend unabhängig vom Salzgehalt erwies, betrug 29,2 bis 36,0\% des Körpergewichts (mit einem Mittel von $33,1 \%$ ) bei Verdünnungsatalyse von Amaranth bzw. 16,7 bis 18,5\% des Körpergewichts (mit einem Mittel von $17,9 \%$ ) bei Verdìnnungsanalyse von ${ }^{14} \mathrm{C}$-Inulin. Die unterschiedlichen $\mathrm{Er}-$ gebnisse, die bei den Bestimmungen mit den beiden Substanzen erhalten worden sind, werden diskutiert. Die weitgehende Konstanz des extrazellulären Raumes trotz beträchtlicher Unterschiede im Salzgehalt zeigt, daß der extrazelluläre Raum kaum einen Einfluß auf die osmoregulatorischen Vorgänge hat. Die rasche Abnahme der Hämolymphproteinkonzentration nach Uberführung verschiedener Süßwasser- und Meereskrebse (DrILHON-Courtors 1934, SIEBERS et al. 1972) in höhere Salinitäten stellt sich somit als eine Verminderung des gesamten Hämolymphproteins im Tier dar, da die Verteilungsräume für das Protein konstant bleiben. Es ist daher wahrscheinlich, daß nach einem Salinitätsanstieg Hämolymphproteine bei der Erhöhung der Konzentration intrazellulärer freier Aminosäuren beteiligt sind.

\section{INTRODUCTION}

The extracellular space of estuarine animals is supposed to play an important role during non-genetic adaptation to fluctuating salinities (SPAARGAREN 1972). By means of determinations of extracellular space and total water content it is possible to obtain data on intracellular water, necessary for the estimation of intracellular concentrations of amino acids, neutral sugars, organic acids, etc. The present paper is designed to investigate the magnitude of the extracellular space in the common shore crab Carcinus maenas exposed to a variety of salinities, by means of the dilution of two different substances ( ${ }^{14} \mathrm{C}$-inulin and the food dye amaranth).

In a former publication SIEBERs et al. (1972) established that haemolymph serum protein in Carcinus maenas decreases from 4.0 to $2.8 \mathrm{~g} / 100 \mathrm{ml}$ within 12 hours after 
transfer from 11 to $38 \% \mathrm{~S}$. On the basis of an estimated extracellular space of $20 \%$ of body weight (BrnNs 1969), the reduction of haemolymph protein amounted to $48 \mathrm{mg} / 20 \mathrm{~g}$ animal (fresh weight). During the same period, the free amino acids in the whole crab increased by $27.8 \mathrm{mg}$. Since only about $1 \%$ of the free amino acids in the crab are dissolved in the haemolymph the increase refers to intracellular concentrations. This sudden reduction in haemolymph protein was interpreted as increased transport of amino acids from the haemolymph to the cell to fill up the intracellular pool of free amino acids. For this interpretation it is necessary to prove that the extracellular spaces of the crabs after transfer from 11 to $30 \% \mathrm{~S}$ had not been changed drastically. Possibly, an unchanged amount of haemolymph protein could have distributed over a larger extracellular volume in the higher salinity, resulting in a diminished concentration $(\mathrm{g} / 100 \mathrm{ml}$ ). Corresponding results on haemolymph proteins were published by Drulfon-Courtors (1934): when freshwater crustaceans, such as Astacus astacus or Telphusa fuviatilis, are transferred to various concentrations of sea water, the protein content of the blood decreases greatly. When C. maenas is transferred from sea water to dilute sea water, the reverse reaction occurs. These responses seem to occur rapidly during the first few hours, and then more slowly (see also Prosser 1952).

\section{MATERIALS AND METHODS}

Male and female specimens of the shore crab Carcinus maenas were collected in October, 1972 from the by-catch of commercial shrimp fishermen at Husum, North Sea coast of Schleswig-Holstein (FRG). At this time of the year the crabs did not molt. They were kept in glass aquaria, containing sea water in concentrations of $10,20,30$, 40 and $50 \% 0 \mathrm{~S}$. The salinities were obtained by dilution of natural sea water from the area of the island of Helgoland, North Sea, with distilled water, or by evaporation. The water was aerated and filtered in circuit. The temperature was kept at $10^{\circ} \mathrm{C}$, and the light rhythm was $10 \mathrm{~h}$ light and $14 \mathrm{~h}$ darkness. Twice weekly the crabs were fed with small pieces of bovine heart. Once a week, half of the water was exchanged. Since preliminary experiments gave no indication of different extracellular spaces (ECS) in regard to sex, we used male and female crabs, randomly distributed within the range of experimental salinities. The literature regarding the correlation between ECS and body weight is contradictory: "In specimens of two species of crayfishes, Orconectes virilis and Procambarus clarki an increase in body weight was correlated with a decrease in weight-specific blood volume measured by inulin distribution" (RIEGEI \& PARKer 1960, p. 302). BnNNs (1969) stated that the ECS of C. maenas (calculated from the distribution of inulin-C14) is obviously independent of sex and body weight. SPAARGAREN (1972) could not find a significant relation between size and extracellular volume in the shrimp Crangon crangon. In view of these contradictions we used only crabs of about the same fresh weight.

After the crabs had been maintained for one month in the different experimental salinities, all individuals with a fresh weight of $20 \pm 4 \mathrm{~g}$ were injected with $50 \mu \mathrm{l}$ inulin-C14 (containing $64 \mathrm{nCi}$ in physiological saline) into the haemocoel by means of a hypodermic syringe attached to a fixed micrometer screw, by which the steel plunger 
could be controlled exactly. Inulin-(carboxylic acid-C14) with a specific activity of $1.28 \mathrm{mCi} / \mathrm{g}$ was obtained from The Radiochemical Centre, Amersham (U.K.). The volume of $50 \mu$ injection solution was calculated not to increase the crabs' expected extracellular fluid volume by more than $1 \%$. After injection the crabs were kept for $1 \frac{1}{2} \mathrm{~h}$ in their different salinities; after this time, about $500 \mu \mathrm{l}$ of haemolymph were withdrawn from the base of a walking leg by a hypodermic needle. After centrifugation $\left(0^{\circ} \mathrm{C}, 5000 \mathrm{~g}\right) 500 \mu \mathrm{l}$ digestin (Merck A.G., Darmstadt) were added to aliquots of $100 \mu$ of overstanding serum, the vials closed and allowed to stand for 1 day at room temperature. After adding $10 \mathrm{ml}$ scintillator solution containing $10 \mathrm{~g} \mathrm{PPO}+$ $0.5 \mathrm{~g}$ POPOP $+50 \mathrm{~g}$ naphthaline per 1 dioxane the samples were counted in a Tracerlab liquid scintillation counter. Corrections were made on the basis of external standard and channel ratio, subsequently followed by internal standardization. The ECS by ${ }^{14} \mathrm{C}$-inulin was calculated from its dilution.

The amaranth dilution method as described by WHEELER (1963) was used as second independent method to realize differences in ECS between an injected polyglycan such as inulin $(\mathrm{M}=6200 \mathrm{~g} / \mathrm{Mol})$ and a commercial food dye such as amaranth (Merck) with a molecular weight of $604 \mathrm{~g} / \mathrm{Mol}$. The crabs were then injected $60 \mu \mathrm{l}$ of amaranth solution, containing $250 \mathrm{mg}$ in $100 \mathrm{ml}$ physiological saline. Haemolymph samples were taken 20 minutes later. After centrifugation $\left(0^{\circ} \mathrm{C}, 5000 \mathrm{~g}\right) 200 \mu \mathrm{l}$ serum were diluted with $1 \mathrm{ml}$ physiological saline and the optical density measured at $521 \mathrm{~nm}$ by a Perkin-Elmer 124 spectrophotometer. The amaranth space was calculated from the dilution of $60 \mu 1$ injection solution in $20 \mathrm{ml}$ of physiological saline.

The properties of substances for calculating the extracellular space are: metabolic inertness, no toxic or pharmaceutic effects, easy determination, and no penetration into the cells or absorption by them (SPAARGAREN 1972). The first three properties seem obvious for a neutral polyglycan and a food dye, the last property was analyzed by washing several pellets after centrifugation of haemolymph which contained floating blood cells, followed by homogenisation. Neither radio-activity from ${ }^{14} \mathrm{C}$-inulin nor colour from amaranth had been attached to the pellets of cells.

\section{RESULTS AND DISCUSSION}

The extracellular space of Carninus maenas does not differ significantly in response to external salinities (Table 1). It varies between 29.2 and $36.0 \%$ with a mean of $33.1 \%$ of body weight when estimated by the amaranth dilution and between 16.7 and $18.5 \%$ with a mean of $17.9 \%$ of body weight when determined by the ${ }^{14} \mathrm{C}$-inulin dilution. For statistical analysis, all comparable groups within the ${ }^{14} \mathrm{C}$ inulin and amaranth dilution method, respectively, were compared with each other by means of the t-test. P-values ranged from 0.16 to 0.96 (amaranth dilution) and from 0.060 to 0.95 ( ${ }^{14} \mathrm{C}$-inulin dilution) with the exception of 0.04 (extracellular spaces of crabs from 40 and $50 \% \mathrm{~S}$, amaranth dilution). The data obtained by ${ }^{14} \mathrm{C}-$ inulin are considered closer to the real extracellular space than those values obtained by the dilution of amaranth. The polyglycan inulin is an uncharged molecule, while amaranth carries charges. That substance used for determinations which leads to the 
Table 1

Carcinus maenas. Extracellular spaces - determined by amaranth dilution method and ${ }^{14} \mathrm{C}$-inulin dilution method - as a funcrion of salinity

\begin{tabular}{|lccc|}
\hline Method & Salinity $\left(^{(\%)}\right)$ & $\begin{array}{c}\text { Extracellular space } \\
(\% \text { of body weight) } \pm \text { standard error }\end{array}$ & $\begin{array}{c}\text { No. of } \\
\text { crabs }\end{array}$ \\
\hline Amaranth & 11.5 & $34.4 \pm 6.2$ & 6 \\
dilution & 17.0 & $32.2 \pm 5.8$ & 13 \\
& 20.5 & $32.5 \pm 5.0$ & 9 \\
& 33.0 & $34.2 \pm 4.7$ & 8 \\
& 39.5 & $36.0 \pm 5.2$ & 5 \\
\hline${ }^{14}$ C-inulin & 49.0 & $29.2 \pm 4.6$ & 8 \\
dilution & 11.0 & mean: 33.1 & 9 \\
& 21.5 & $18.4 \pm 4.3$ & 7 \\
& 30.5 & $16.7 \pm 1.3$ & 9 \\
& 40.5 & $17.8 \pm 1.4$ & \\
\hline & 49.0 & $18.5 \pm 1.5$ & \\
\hline
\end{tabular}

smallest extracellular spaces has vanished from its distribution area in the smallest amounts and appears to fulfill best the demands for substances to estimate extracellular spaces as described in the chapter "Introduction". The inulin space of $17.9 \%$ of body weight corresponds well to that of Binns (1969), which amounts to $19.4 \%$ (Table 2).

Results of Gross \& Marshall (1960) seem contradictory in comparison to the present results: when the euryhaline shore crab Pachygrapsus crassipes was removed after 3 days immersion in 50, 100 and 150\% sea water the extracellular spaces of distribution of ${ }^{14} \mathrm{C}$-tagged sucrose one minute after injection were $15.4,18.7$ and $26.7 \%$ of body weight (Table 2 ).

Our findings are in accordance with results of LocKwooD \& INMAN (1973a, b; Table 2) who could not find evidence to suggest changes in the extracellular space of the amphipod Gammarus duebeni, which had been fully acclimated to widely different salinities ( $2 \%$ and $100 \%$ sea water). The extracellular spaces are remarkably constant. Extracellular spaces in the euryhaline cerithiid mollusc Melanopsis trifasciata are - if existent - small over a wide range of salinities (56.1\% of body water in $0 \%$ sea water, $65 \%$ in $30 \%$ and $53.8 \%$ in $50 \%$ sea water); the water content of the soft parts-without shell - remains nearly unchanged: $85.1 \%$ of fresh weight in $0 \%$ and $82.6 \%$ in $75 \%$ sea water (BEDFORD 1972). When the polychaete Nereis succinea is maintained for 5 or more days in 100 and $20 \%$ artificial sea water at $15^{\circ}$ to $18^{\circ} \mathrm{C}$, the extracellular spaces $\left({ }^{14} \mathrm{C}\right.$-inulin) amount to $15.6 \pm 1.1 \%$ of body weight $(\mathrm{n}=63)$ and $15.3 \pm$ $1.2(\mathrm{n}=53)$, respectively (FreEL et al. 1973).

It does not seem possible to compare extracellular spaces of whole living animals with those of isolated organs: the inulin space in the adductor muscle of the oyster Gryphaea ungulata is reduced in decreasing salinities. It amounts to $9.6 \%$ of fresh weight in sea water and $5.9 \%$ in $50 \%$ sea water (BRICTEUX-GREGorre et al. 1964).

On the other hand, LANG \& GAINER (1969) equilibrated for 10 hours at $4^{\circ} \mathrm{C}$ whole adductor muscles from walking legs of the blue crab Callinectes sapidus and 


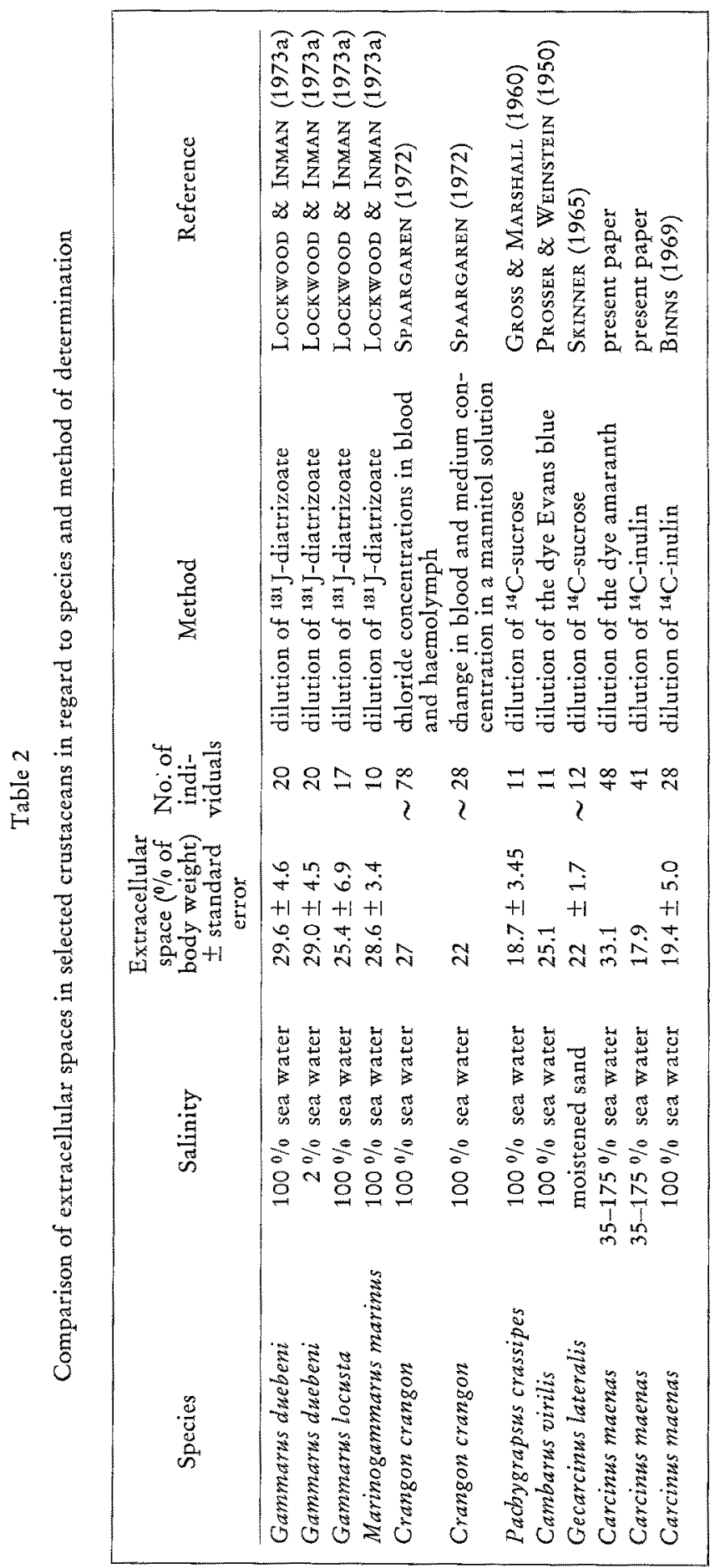


then transferred the muscles to experimental salinities for 6 hours at $20^{\circ} \mathrm{C}$ with different osmotic pressures $\left(\pi_{1}=\right.$ isotonic Na-saline, $\pi_{2}=$ hypotonic Na-saline, where $\pi_{1} /$ $\left.\pi_{2}=1.5\right)$. The swelling of the muscles in hypotonic saline is readily compensated by volume re-adjustment within 6 hours. The extracellular spaces measured by the ${ }^{14} \mathrm{C}$ inulin dilution method are nearly unchanged. They amount to $22.4 \pm 2.1 \%$ of muscle fresh weight in isotonic $\mathrm{Na}$-saline and $21.4 \pm 1.4 \%$ in hypotonic $\mathrm{Na}$-saline.

For Carcinus maenas it seems well demonstrated that the extracellular space amounts to $18-20 \%$ of body weight (inulin distribution). This space seems not to be altered in consequence of a transfer to a wide variety of salinities. From this finding can be deduced that in $C$. maenas a decrease in serum proteins after a transfer from 11 to $38 \% \mathrm{~S}$ also means a decrease in the total amount of serum proteins. Since this decrease ( $48 \mathrm{mg}$ protein $/ 20 \mathrm{~g}$ animal) is similar in magnitude to the increase of intracellular free amino acids ( $28 \mathrm{mg} / 20 \mathrm{~g}$ animal), it seems likely that haemolymph proteins participate in the increase of intracellular free amino acids during isosmotic intracellular regulation.

\section{SUMMARY}

1. In shore crabs Carcinus maenas, which had been maintained for one month in 10 , $20,30,40$, and $50 \%$ salinity, the extracellular space was estimated by means of the dilution of the food dye amaranth and the polyglycan ${ }^{14} \mathrm{C}$-inulin.

2. The extracellular space does not differ significanty in response to the external salinity. It varies between 29.2 and $36.0 \%$ (with a mean of $33.1 \%$ ) of body weight when estimated by dilution of amaranth and between 16.7 and $18.5 \%$ (with a mean of $17.9 \%$ ) of body weight when estimated by ${ }^{14} \mathrm{C}$-inulin dilution. Differences of values in regard to the substances used for estimation are discussed.

3. The results confirm that the magnitude of the extracellular space is not involved in phenomena of osmoregulation.

4. The rapid reduction in the concentration of haemolymph proteins after transfer of freshwater and marine decapods from lower to higher salinities (DriLHon-CourTOIS 1934, Siebers et al. 1972) implies, on the basis of the present results, also a reduction in the total amount of haemolymph protein in the crab, since the proteindistribution volume remains unchanged within a wide variety of salinities. The assumption that haemolymph proteins participate in the increase of intracellular free amino acids during isosmotic intracellular regulation is confirmed.

\section{LITERATURE CITED}

BEDFord, J. J., 1972. Osmoregulation in Melanopsis trifasciata. II. The osmotic pressure and the principal ions of the haemocoelic fluid. Physiol. Zoöl. 45, 261-269.

Binns, R., 1969. The physiology of the antennal gland of Carcinus maenas (L.) II. Urine production rates. J. exp. Biol. 51, 11-16.

Bricteux-Grégotre, S., Duchîteaumbosson, Gh., Jeuntaux, C. \& Florkin, M., 1964. Constituants osmotiquement actifs des muscles adducteurs de Gryphaea ungulata adapté à l'eau de mer ou à l'eau saumâtre. Archs. int. Physiol. Biochim. 72, 835-842. 
Drilhon-Courtors, A., 1934. De la régulation de la composition minérale de l'hémolymphe des crustacés. Annls Physiol. Physicochem. biol. 10, 377-414.

Freel, R. W., Medler, S. G. \& Clark, M. E., 1973. Solute adjustments in the coelomic fluid and muscle fibers of a euryhaline polychaete, Neanthes succinea, adapted to various salinities. Biol. Bull. mar. biol. Lab., Woods Hole, 144, 289-303.

Gross, W. J. \& Marshall, L. E, 1960. The influence of salinity on the magnesium and water fluxes of a crab. Biol. Bull. mar. biol. Lab., Woods Hole, 119, 440-453.

LANG, M. A. \& GAINER, H., 1969. Isosmotic intracellular regulation as a mechanism of volume control in crab muscle fibres. Comp. Biochem. Physiol. 30, 445-456.

LOCK wOOD, A. P. M. \& INMAN, C. B. E., 1973a. The blood volume of some amphipod crustaceans in relation to the salinity of the environment they inhabitat. Comp. Biochem. Physiol. 44, 935-941.

- - 1973b. Water uptake and loss in relation to the salinity of the medium in the amphipod crustacean Gammarus duebeni. J. exp. Biol. 58, 149-163.

Prosser, C. L., 1952. Comparative animal physiology. Saunders, Philadelphia, 888 pp.

- \& Weinstein, S. J. F., 1950. Comparison of blood volume in animals with open and with closed circulatory systems. Physiol. Zoöl. 23, 113 124.

Rifgel, J. A. \& Parker, R. A., 1960. A comparative study of crayfish blood volumes. Comp. Biochem. Physiol. 1, 302-304.

Stebers, D., Lucu, C., Sperling, K.-R. \& EberlerN, K., 1972. Kinetics of osmoregulation in the crab Carcinus maenas. Mar. Biol. 17, 291-303.

SKINNER, D. M., 1965. Amino acid incorporation into protein during the molt cycle of the land crab, Gecarcinus lateralis. J. exp. Zool. 160, 225-234.

SPAARgaren, D. H., 1972. Determination of the extracellular volume in the shrimp Crangon crangon (L.). Comp. Biochem. Physiol. 43 (A), 843-848.

WheEler, R. E., 1963. Studies on the total hemocyte count and hemolymphe volume in Periplaneta americana (L.) with special reference to the last moulting cycle. J. Insect Physiol. 9, 223-235.

First author's address: Dr. D. Siebers

Biologische Anstalt Helgoland (Zentrale)

2000 Hamburg 50

Palmaille 9

Federal Republic of Germany 